\title{
Profile of Transfusion Transmitted Infections - A Study among Blood Donors
}

\author{
Lekshmi Leela Rajan¹, M.S. Suma², Harikumar S. ${ }^{3}$
}

${ }^{1}$ Department of Transfusion Medicine \& Immunohematology, Government Medical College Kollam, Kerala, India. ${ }^{2}$ Department of Transfusion Medicine \& Immunohematology, Government

Medical College, Kottayam, Kerala, India. ${ }^{3}$ National Health Mission, Kollam, Kerala, India.

\section{ABSTRACT}

\section{BACKGROUND}

Transfusion of blood and blood products is an essential component of patient care in various health care settings. Blood is collected from non-remunerated donors. Many infections can spread through the transfusion of blood and blood components. Testing of donor blood for infectious agents prior to transfusion of blood products increases blood safety. Mandatory testing of five transfusion transmitted infections is done prior to transfusion following manufacturer's instructions and quality specifications. Prevalence study will help the blood transfusion services to select and implement the strategies effectively for blood safety.

\section{METHODS}

This is a descriptive study based on retrospective collection of data from available records. Donor results were recorded and maintained to ensure the traceability of specific donor. The data was collected from the blood donor records and registers pertaining to the 10 year period from 2007 to 2016 . Samples seroreactive for human immunodeficiency virus (HIV) antibodies, hepatitis B, hepatitis C, malaria and syphilis were recorded and analysed.

\section{RESULTS}

A total of 1,73,027 donors donated blood during the ten-year period. Of these 1 , 65,824 were males and 7203 were females. Male to female ratio was 23:1. Hepatitis B surface antigen (HBsAg) seroreactivity is the most common which came to about 419 in this 10 -year period with a prevalence rate of $0.24 \%$ or 24 reactive cases in every 10,000 donors. Prevalence rate of Hepatitis C and HIV infection was $0.09 \%$ and $0.035 \%$ respectively. Rapid plasma reagin (RPR) and malaria reactivity was $0.02 \%$.

\section{CONCLUSIONS}

As safe blood supply is an important strategy of blood transfusion services, newer diagnostic tools should be implemented nationwide to overcome the problems with the window period and to detect infections with variant strains.

\section{KEY WORDS}

Prevalence, Transfusion Transmitted Infections, HIV, Hepatitis B and Hepatitis C, Syphilis
Corresponding Author: Dr. Lekshmi Leela Rajan, Associate Professor (CAP), Department of Transfusion Medicine \& Immunohematology, Government Medical College, Kollam, Kerala, India.

E-mail: lekshmraj@gmail.com

DOI: $10.14260 /$ jemds/2021/186

How to Cite This Article:

Rajan LL, Suma MS, Harikumar S. Profile of transfusion transmitted infections - a study among blood donors. J Evolution Med Dent Sci 2021;10(12):861-865, DOI: 10.14260/jemds/2021/186

Submission 18-11-2020,

Peer Review 25-01-2021,

Acceptance 02-02-2021,

Published 22-03-2021.

Copyright (C) 2021 Lekshmi Leela Rajan et al. This is an open access article distributed under Creative Commons Attribution License [Attribution 4.0 International (CC BY 4.0)] 


\section{BACKGROUND}

Blood transfusion system is an important component of health care system that has the responsibility of ensuring safe blood products for transfusion. Transfusion transmitted infections are those infections transmitted from one person to another through blood and blood products. These can be caused by various microbial agents like bacteria, viruses, parasites and prions. Patients during transfusion therapy are usually given large volumes of blood products. Transfusion process can lead to infectious and non-infectious complications in the recipients. Transfusion transmitted infections (TTI) continues to be a major delayed complication of blood transfusion. Transfusion transmitted infections (TTI) are caused by microbial agents that can cause morbidity and mortality in the recipients. Most of these microbial agents cause mild or asymptomatic infections. If symptomatic, would have long incubation period, sometimes takes months to years to develop symptoms. Some microbial agents may be in carrier state and few may cause latent infection and can remain stable in cold storage. The window period describes microbial agents not detectable in a screening test even though the individual may be infected. With widespread usage of blood components, infection can spread to multiple patients from a single donor. Major threats that remain undetected are seronegative donors in window period donating blood, presence of variant strains and immune silent donors.

Among the transfusion transmitted infections, HIV infection is most dreadful as there is no cure for it. HIV can be transmitted sexually, vertically or through transfusing contaminated blood products..$^{1,2}$

Prevalence studies of TTI are mainly done in blood centres, where blood is collected from voluntary non-remunerated donors and that can inform about these diseases to the community. ${ }^{3-6}$

Spread of transfusion transmitted infections (TTI) can be nosocomial when invasive medical procedures are done using contaminated equipments. Most of the TTI are sexually transmitted. Vertical transmission is from mother to baby which can occur at birth. High risk group include sex workers and intravenous drug users. ${ }^{7-11}$ Based on prevalence studies to enhance blood safety, quality management strategies should be implemented right from donor selection to various tests used to detect the diseases.

\section{METHODS}

This was a case record based descriptive study conducted in a tertiary care centre which is a Government Medical College in Kerala. The study was based on retrospective collection of data from available records. The data was collected from the blood donor records and registers pertaining to the 10 year period from 2007 to 2016. All blood units collected in blood banks were tested mandatory for five diseases. Consent for testing was obtained from each donor prior to blood donation. Healthy blood donors were selected by a thorough screening process which included a detailed history taking and physical examination. The donor serum samples were analysed to detect anti HIV antibodies by enzyme-linked immunosorbent assay (ELISA) test. The donor serum samples were analysed to detect anti HCV antibodies by ELISA test. HBsAg antigen detecting ELISA test was used for Hepatitis B detection. Syphilitic antibody detection was done by RPR tests. Malarial antigen detection was done using immune-chromatographic pan malarial cards. Seroreactivity to infections were recorded in the respective screening registers. All the samples that were found reactive on initial testing were repeated in duplicate with the same samples and samples from the blood bags. Samples that were found reactive on repeat testing were considered as positive and included in the study. Any equivocal or indeterminate samples were discarded considering the safety of blood transfusion but were not included in the study.

\section{Statistical Analysis}

Descriptive analysis was done on collected data. Estimation of total prevalence during the period was done along with the annual prevalence from the collected data to find out trends. The proportion of positive cases among male and female donors was estimated and chi-square test for proportions was done to find out any significant difference between them.

\section{RESULTS}

In blood centre, donors were screened before donation using standard questionnaire. Anthropometric examination and physical examination including vitals were done. Consent for blood donation and screening tests were taken prior to blood donation. Counselling was given to donors before donation. They were taught about the need and importance of regular voluntary donations and importance of screening for high risk diseases. Those who were found fit for donation only were given unique identification numbers and sent to blood collection area; others depending on various reasons, were deferred temporarily or permanently. Donor details were entered in appropriate registers. Soon after completing phlebotomy of donors, blood samples were collected in vials for doing infectious diseases screening and results were entered in registers.

In the study subjects of $173027,95.84 \%$ were males which indicated that males were predominant donors in the blood centre. Female donors were only $4.16 \%$ of total donors. Data pertaining to seroreactive samples was recorded.

\begin{tabular}{|cccc|}
\hline Year & $\begin{array}{c}\text { Anti-HIV } \\
\text { Antibody } \\
\text { Reactivity }\end{array}$ & $\begin{array}{c}\text { Total Annual } \\
\text { Donations }\end{array}$ & $\begin{array}{c}\text { Anti-HIV Antibodies } \\
\text { Prevalence in Percentage }\end{array}$ \\
2007 & 23 & 14226 & 0.16 \\
2008 & 4 & 16742 & 0.02 \\
2009 & 3 & 15604 & 0.019 \\
2010 & 2 & 16703 & 0.012 \\
2011 & 0 & 16729 & 0 \\
2012 & 1 & 17160 & 0.005 \\
2013 & 2 & 16365 & 0.012 \\
2014 & 10 & 17863 & 0.056 \\
2015 & 9 & 20059 & 0.045 \\
2016 & 6 & 21576 & 0.03 \\
Total & 60 & 173027 & 0.035 \\
\hline \multicolumn{4}{r}{ Table 1. Prevalence of HIV } \\
\hline
\end{tabular}

Prevalence of HIV antibodies was $0.035 \%$ which was less than national average of $0.19 \%$. That was 3.5 for every 10,000 
donors. All these seroreactive donors were males. Males constituted to $95.84 \%$ of total donors. There was no coinfection of other TTI and HIV recorded. There was a decreasing trend in the prevalence of HIV infection among donors.

\begin{tabular}{|c|c|c|c|c|}
\hline $\begin{array}{l}\text { Year of } \\
\text { Study }\end{array}$ & $\begin{array}{c}\text { HBsAg } \\
\text { Reactivity }\end{array}$ & $\begin{array}{l}\text { Anti HCV } \\
\text { Reactivity }\end{array}$ & $\begin{array}{l}\text { Hepatitis B } \\
\text { and } C\end{array}$ & $\begin{array}{l}\text { Total TTD } \\
\text { Reactivity }\end{array}$ \\
\hline 2007 & 61 & 43 & 104 & 133 \\
\hline 2008 & 74 & 22 & 96 & 110 \\
\hline 2009 & 58 & 7 & 65 & 77 \\
\hline 2010 & 55 & 13 & 68 & 79 \\
\hline 2011 & 31 & 6 & 37 & 43 \\
\hline 2012 & 34 & 2 & 36 & 41 \\
\hline 2013 & 26 & 2 & 28 & 32 \\
\hline 2014 & 22 & 27 & 49 & 79 \\
\hline 2015 & 21 & 16 & 37 & 52 \\
\hline 2016 & 37 & 21 & 58 & 64 \\
\hline Total & 419 (59\%) & $159(22.4 \%)$ & $578(81.4 \%)$ & 710 \\
\hline
\end{tabular}

$81.4 \%$ of total transfusion transmitted infections were caused by hepatitis B and C. As majority of the donor population were males, the seroreactivity was also high in males, $98.9 \%$. Chi-square test was done, $\mathrm{P}$-value was 0.00 and hence statistically significant difference was there in the proportion of hepatitis B positive among males and females. Hepatitis B reactivity was $59 \%$ of all other transfusion transmitted infections. Reactivity was high in the first five years than later years.

\begin{tabular}{|c|c|c|c|c|c|}
\hline Year & $\begin{array}{c}\text { HIV } \\
\text { Reactivity }\end{array}$ & $\begin{array}{c}\text { HBsAg } \\
\text { Reactivity }\end{array}$ & $\begin{array}{l}\text { Anti HCV } \\
\text { Reactivity }\end{array}$ & $\begin{array}{l}\text { RPR Test for } \\
\text { Syphilis } \\
\text { Reactivity }\end{array}$ & $\begin{array}{l}\text { Total TTD } \\
\text { Positivity }\end{array}$ \\
\hline 2007 & 23 & 61 & 43 & 6 & 133 \\
\hline 2008 & 4 & 74 & 22 & 9 & 110 \\
\hline 2009 & 3 & 58 & 7 & 4 & 77 \\
\hline 2010 & 2 & 55 & 13 & 5 & 79 \\
\hline 2011 & 0 & 31 & 6 & 4 & 43 \\
\hline 2012 & 1 & 34 & 2 & 2 & 41 \\
\hline 2013 & 2 & 26 & 2 & 3 & 32 \\
\hline 2014 & 10 & 22 & 27 & 2 & 79 \\
\hline 2015 & 9 & 21 & 16 & 1 & 52 \\
\hline 2016 & 6 & 37 & 20 & 1 & 64 \\
\hline Total & $60(8.45 \%)$ & 419 (59\%) & $159(22.4 \%)$ & 37 (5.2\%) & 710 \\
\hline
\end{tabular}

\begin{tabular}{|ccccc|}
\hline $\begin{array}{c}\text { Year of } \\
\text { Study }\end{array}$ & $\begin{array}{c}\text { Prevalence of } \\
\text { HIV } \\
\text { Antibodies in } \\
\text { Percentage }\end{array}$ & $\begin{array}{c}\text { Prevalence of } \\
\text { Hepatitis B in } \\
\text { Percentage }\end{array}$ & $\begin{array}{c}\text { Prevalence of } \\
\text { Hepatitis C in } \\
\text { Percentage }\end{array}$ & $\begin{array}{c}\text { Prevalence of } \\
\text { Syphilitic } \\
\text { Antibody in } \\
\text { Percentage }\end{array}$ \\
2007 & 0.16 & 0.43 & 0.30 & 0.04 \\
2008 & 0.02 & 0.44 & 0.13 & 0.05 \\
2009 & 0.019 & 0.37 & 0.04 & 0.03 \\
2010 & 0.012 & 0.33 & 0.08 & 0.03 \\
2011 & 0 & 0.19 & 0.04 & 0.02 \\
2012 & 0.005 & 0.2 & 0.01 & 0.01 \\
2013 & 0.012 & 0.16 & 0.01 & 0.02 \\
2014 & 0.056 & 0.12 & 0.15 & 0.01 \\
2015 & 0.045 & 0.11 & 0.08 & 0.005 \\
\hline 2016 & 0.03 & 0.17 & 0.10 & 0.005 \\
Total & $\mathbf{0 . 0 3 5}$ & $\mathbf{0 . 2 4}$ & $\mathbf{0 . 0 9}$ & $\mathbf{0 . 0 2}$ \\
\hline \multicolumn{5}{r}{ Table 4. Prevalence of TTI } \\
\hline
\end{tabular}

$59 \%$ of total seroreactive cases was by hepatitis B, then comes hepatitis C, $22.4 \%$, HIV reactivity in the third position, $8.45 \%$, RPR reactivity was $5.2 \%$ and malarial antigen detection was in $4.9 \%$.
Prevalence of HIV antibodies is $0.035 \%$, HBsAg is $0.24 \%$, anti HCV antibodies is $0.09 \%$ and RPR reactivity is $0.02 \%$. Hepatitis B is most common TTI, then comes hepatitis C, HIV and syphilis.

Seroreactivity to syphilis antibody is $0.02 \%$ which is less than national average. There is a decreasing trend in RPR reactivity over the years.

\section{DISCUSSION}

Screening of blood for infectious diseases represents an important strategy of blood safety. National AIDS Control Organisation recorded that the HIV prevalence in adults in the age group of 15 - 49 years was $0.26 \%$. In Kerala adult HIV prevalence was below $0.20 \% .3,4$ Prevalence of seroreactivity against HIV was studied among blood donors from different parts of the country. In an article from North India the prevalence rate was of $0.24 \% .{ }^{5}$ A study from South India, Kerala showed a prevalence rate of $0.2 \% .^{6}$ In the present study, prevalence rate is $0.035 \%$, which is lower than National average of $0.19 \%$. for the five mandatory tests, seroreactivity to HIV is $8.45 \%$ which is in the third position, hepatitis B and $\mathrm{C}$ in first and second position respectively. Present study also showed a decreasing trend in HIV infections. HIV transmission through blood is still a problem if the diagnostic tests of the donor blood in the window period fails to detect it.

Hepatitis B virus (HBV) is an enveloped DNA virus, a member of hepadnavirus group. HBV once in the bloodstream travels to the liver where it replicates in the hepatocytes. The disease can cause chronic infections, liver damage, liver cirrhosis and liver cancers. The incubation period may vary from 30 to 180 days. Perinatal transmission and horizontal transmission of hepatitis $\mathrm{B}$ virus occur in endemic regions where the prevalence of $\mathrm{HBsAg}$ is high $\geq 8 \% .7,8$ In India, prevalence of hepatitis $B$ among general population comes in intermediate zone which is $2-7 \% .{ }^{9}$ Hepatitis B prevalence in the present study is $0.24 \%$, against the National average of 0.98. Out of the five transfusion transmitted infections, hepatitis B constitutes to $59 \%$ of infection. Co-infection of HIV and HBV are common, but no such co-infections were detected in the present study.

Hepatitis $\mathrm{C}$ virus is a contagious, blood borne virus capable of causing asymptomatic infections. It can cause both acute and chronic infections. Hepatitis $\mathrm{C}$ virus causes chronic progressive liver diseases leading to liver damage, liver failure, liver cirrhosis and cancers. Hepatitis $\mathrm{C}$ cancers are one of the most common indication for liver transplantation. Though antiviral drugs are there for treatment of Hepatitis $C$ but no effective vaccine is available. Exposure to small quantities of contaminated blood can spread the disease. It can spread through contaminated needles and if infection control practices are not efficient can spread through hospitals, in communities with high prevalence of Hepatitis C. Many are unaware of their infection as 80 percent of infected persons are not having any symptoms.10,11 Chi-square test was performed but failed to find out the statistical significance of prevalence in male and females for anti HCV reactivity. No significance was detected as P-value 0.07 . 


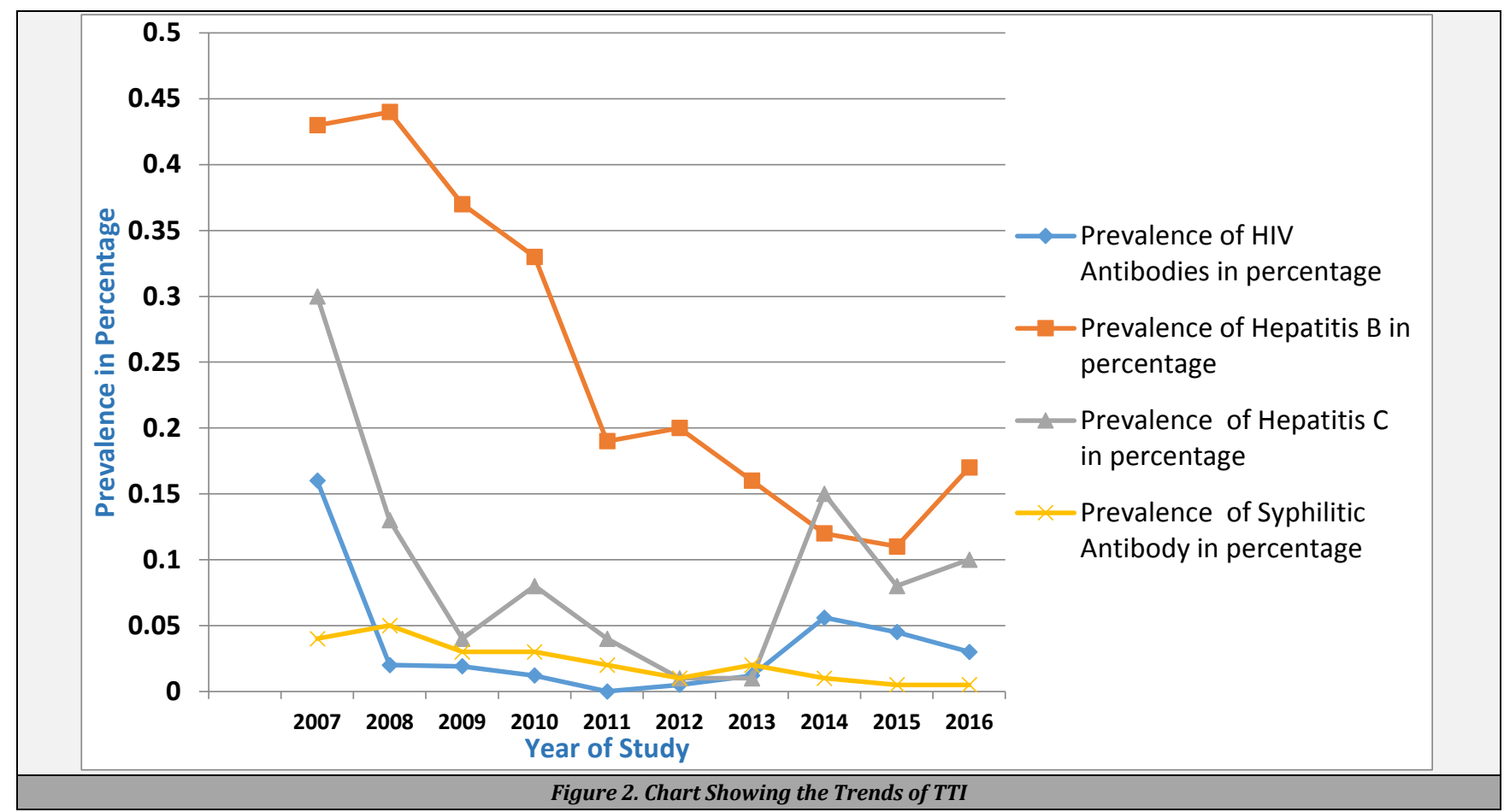

Some region are endemic for HBV with prevalence more than or equal to $8 \% .^{12} \mathrm{HBV}$ prevalence from different parts of India vary, and in one study, an increasing trend of HIV, HBV and HCV were observed. ${ }^{13}$ A study done in North India found that $0.39 \%$ donors were reactive to $\mathrm{HCV}$ antibody detection tests. ${ }^{14}$ Another blood donor study from Andhra Pradesh showed a seroreactivity of HIV was $0.39 \%$ and syphilis 0.08 $\% .{ }^{15}$ As mode of spread was through sexual route, HIV and syphilis coinfections were common. A national household survey found out that syphilis prevalence was high in HIV infected people. ${ }^{16}$ But no such coinfections were noted in the present study.

The prevalence of TTI in a region reflects the prevalence of infections in donor population. If the prevalence of TTI is high in an area, the prevalence in donor population will be high and risk of transmission to recipients will also be high. Effective steps have to be implemented for blood safety. Quality of blood transfusion services has to be strengthened nationwide right from donor selection to judicious use of blood products in the recipient.

\section{CONCLUSIONS}

Safe blood supply is an important strategy of blood transfusion services. Non-remunerated voluntary donor selection is very important to minimise the risk of infections. The lower prevalence of transfusion transmitted infections in the donor population reduces the rate of discarding of blood products. Newer diagnostic tools have to be implemented nationwide to detect infections in the window period and to detect infections with variant strains.

Data sharing statement provided by the authors is available with the full text of this article at jemds.com.

Financial or other competing interests: None.
Disclosure forms provided by the authors are available with the full text of this article at jemds.com.

\section{REFERENCES}

[1] World health organization factsheet on HIV. https://www.who.int/news-room/fact-sheets/detail/hiv -aids accessed on 20 - 11 - 2020

[2] CDC data. Accessed on 20/11/2020. https://www.cdc.gov/hiv/basics/statistics.html

[3] National Aids Control Organization data. naco.gov.in/sites/default/files/Annual\%20Report $\% 202015$ - 16.pdf

[4] National Aids Control Organization data. http://www.naco.gov.in/sites/default/files/India \%20HIV \%20Estimations \%202015.pdf

[5] Makroo RN, Hegde V, Choudhry M, et al. Seroprevalence of infectious markers and their trends in blood donors in a hospital based blood bank in North India. Indian J Med Res 2015;142(3):317-22.

[6] Mathai J, Sulochana PV, Satyabhama S, et al. Profile of transfusion transmissible infections and associated risk factors among blood donors of Kerala. Indian J Pathol Microbiol 2002;45(3):319-22.

[7] World Health Organization factsheet on Hepatitis B https://www.who.int/news-room/factsheets/detail/hepatitis-b

[8] CDC Hepatitis B. https://www.cdc.gov/hepatitis/hbv/index.htm accessed on $21 / 11 / 2020$

[9] Puri P. Tackling the hepatitis b disease burden in India. J Clin Exp Hepatol 2014;4(4):312-9.

[10] CDC Hepatitis C. https://www.cdc.gov/hepatitis/hcv/index.htm accessed on 20 - 09 - 2020 
[11] World health organization factsheet on Hepatitis C available in https://www.who.int/news - room/fact sheets/detail/hepatitis - c accessed on 21/11/2020

[12] Viet L, Lan NTN, Ty PX, et al. Prevalence of hepatitis B and Hepatitis $C$ in potential blood donors in rural Vietnam. Indian J Med Res 2012;136(1):74-81.

[13] Patel SV, Popat CN, Mazumdar VS, et al. Seroprevalence of HIV, HBV, HCV and syphilis among blood donors at blood bank of a tertiary care hospital. Int J Med Sci Public Health 2013;2(3):749-50.
[14] Makroo RN, Walia RS, Chowdhry M, et al. Seroprevalence of anti-HCV antibodies among blood donors of North India. Indian J Med Res 2013;138(1):125-8.

[15] Bhawani Y, Rao PR, Sudhakar V. Seroprevalence of transfusion transmissible infections among blood donors in a tertiary care hospital in Andra Pradesh. Biology and Medicine 2008;2(4):45-8.

[16] Mutagoma M, Remera E, Sebuhoro D, et al. The prevalence of syphilis infection and its associated factors in the general population of rwanda: a national household-based survey. Journal of Sexually Transmitted Diseases 2016;2016:4980417. 